\title{
Introduction
}

\section{VIVIAN NUTTON}

Epidemic disease has long exercised a fascination for historians. The disease that devastated Athens in $430 \mathrm{BC}$ and recurred a few years later drew from the contemporary historian Thucydides some of his most memorable pages. He portrayed it as a social as well as a medical crisis, a metaphor for the disintegration of Athenian society under the strains of a major war. ${ }^{1}$ His detailed description, based on his own personal experiences of the disease, is the most extensive account of an ancient epidemic disease to have survived, and provided the model for innumerable imitators, like the Latin poet Lucretius or the Byzantine historian, Procopius. ${ }^{2}$ Indeed, so influential was this description that the Roman satirist Lucian, in the 160s, could expect his audience to appreciate the joke when he described how a certain Crepereius Calpurnianus of Pompeiopolis, writing his history of Rome's wars with Parthia, had transposed large sections of this account from Athens to the distant Syrian city of Nisibis. ${ }^{3}$ Thucydides' eyewitness testimony, allied to the apparent precision of his language, attracted the attention of doctors at least from the time of Galen (129-c. 216), who bemoaned the fact that the historian did not know enough medicine fully to single out the most significant features of the disease. Had Hippocrates been the observer, future doctors could have relied on his information to use in their own practices. ${ }^{4}$

Modern historians are no less frustrated than Galen, but for different reasons. Thucydides' focus on Athens (and her plague-stricken outpost at Potidaea in northern Greece) robs us of a proper context, for we cannot give precision to Thucydides' passing comment that the disease was felt elsewhere, or link it to other outbreaks of epidemic disease recorded for other places around the same time. The disease itself defies identification in modern terms, and a long series of doctors and historians have raised a string of possibilities, only for the weaknesses in their theories to be denounced by others. ${ }^{5}$ Even the recent announcement that archaeological evidence now proves the plague to have been typhoid has been beset by doubts about the DNA analysis and the dating and context of the alleged plague grave. ${ }^{6}$

Professor Vivian Nutton, The Wellcome Trust Centre for the History of Medicine at UCL, 183 Euston Road, London NW1 2BE, UK.

\footnotetext{
${ }^{1}$ Thucydides, History, 2, 47-54, 58.

${ }^{2}$ Jürgen Grimm, Die literarische Darstellung der Pest in der Antike und in der Romania, Munich, W Fink, 1965.

${ }^{3}$ Lucian, How to write history, 15 . Whether Crepereius was a historical figure, as most scholars think, or a product of Lucian's lively imagination is not clear.

${ }^{4}$ Fridolf Kudlien, 'Galens Urteil über die Thukydideische Pestbeschreibung', Episteme, 1971, 5: 132-3.

${ }^{5}$ James Longrigg, 'The great plague of Athens', Hist. Sci., 1980, 18: 209-25, provides a good survey of earlier literature, and is extended by Ann G Carmichael, 'Plague of Athens', in Kenneth J Kiple (ed.), The Cambridge world history of human disease, Cambridge University Press, 1993, pp. 934-7. More recent suggestions include toxic shock syndrome and a variety of viruses.

${ }^{6}$ Manolis J Papagrigorakis, Christos Yapijakis, Philippos N Synodinos, and Effie Baziotopoulou-Valavani, 'DNA examination of ancient dental pulp incriminates typhoid fever as a probable cause of the plague of Athens', Int. J. Infect. Dis., 2006, 10 (3): 206-14. The authors' precise dating of the grave depends on Thucydides' account:
} 


\section{Vivian Nutton}

No less controversial have been attempts to identify and explain the epidemic disease that ravaged Europe and the Middle East between 1347 and 1350, and that recurred again at regular intervals until the twentieth century, although major outbreaks ended in England in 1665 and in western Europe with that of Marseilles and Provence in 1720-2, and of Messina in 1770-1. There is no shortage of contemporary evidence, from chroniclers like Gabriele de' Mussis of Piacenza, who wrote his Historia de morbo in 1348, through novelists, like Boccaccio, who set his Decameron against the onset of the epidemic, to an abundance of medical writers offering observations and advice. ${ }^{7}$ Archival documents, whether the decisions of councils or the more prosaic records of the dead, supplement the vagaries of personal judgment with the conclusions of authority or the dry data of statistics. Archaeology has recently come to play a role, both by uncovering sites linked to this epidemic and, thanks to DNA analysis, by holding out the prospect of identification of its causative agent (or agents). Together they have allowed the creation of substantial annals of plague, setting out at length the places and dates of an outbreak of epidemic disease somewhere in Europe or beyond. ${ }^{8}$

This information in turn was used by generations of doctors as part of their attempts to combat plague. The same language, the same observations, even the same recommendations were constantly repeated. Writers in eighteenth-century Norway described the manifestations of plague in their community in exactly the same words as a writer on plague four hundred years earlier, a continuity that fits easily, perhaps too easily, with the assertions of modern plague specialists that the symptoms of bubonic plague are unmistakable and may well have been constant throughout the period of this volume. Doctors had no hesitation in utilizing earlier material to assist them in their own battles against plague. Girolamo Mercuriale, in his treatise De pestilentia, published in 1577 , drew on a wide range of medical and non-medical authorities from the past to establish his own explanation of contemporary plague and to justify his own, somewhat dubious, behaviour in the great plague of Venice in $1576 .{ }^{9}$ His approach, though more academic, was little different from that of Pierre Costan, a doctor from Rodez in central France, who inserted around 1560 into the margins of his collection of plague tracts his own observations on plague in his town, comparing and contrasting his experiences with those described in his books. ${ }^{10}$

Although historians and chroniclers continued to describe the ravages of plague, a proper historical appreciation of plague does not begin to appear until the end of the eighteenth century with Christian Gottfried Gruner's studies of epidemic disease, and Kurt

without Thucydides, the dating limits became considerably wider, to the fourth to fifth century BC. Cf. also Antoine, below, p. 112.

${ }^{7}$ Many of these accounts are now available in English, with an excellent commentary, in Rosemary Horrox (trans. and ed.), The Black Death, Manchester University Press, 1994.

${ }^{8}$ Principal among the older literature is Alfonso Corradi, Annali delle epidemie occorse in Italia dalle prime memorie fino al 1850, 5 vols, Bologna, Gamberini e Parmeggiani, 1865-94.

${ }^{9}$ Vivian Nutton, 'With benefit of hindsight: Girolamo Mercuriale and Simone Simoni on plague', Medicina e Storia, 2006, 11: 5-19; Richard J Palmer, 'Mercuriale and the plague of Venice', in Alessandro Arcangeli and Vivian Nutton (eds), Girolamo Mercuriale, Florence, Olschki, 2008, pp. 51-65.

${ }^{10}$ Vivian Nutton, 'Books, printing and medicine in the Renaissance', Medicina nei Secoli, 2005, 17 (2): 421-42, at p. 436 . 


\section{Introduction}

Polycarp Sprengel's survey of plague in his Beiträge zur Geschichte der Medicin. ${ }^{11}$ Provoked by a question about the death of Petrarch's Laura, Sprengel proceeded to collect as many sources as possible, historical as well as medical, that might throw light on the Black Death. ${ }^{12}$ How widely read his fine essay was is difficult to determine, since it appeared in the first volume of what became an occasional series of historical papers. Although Sprengel anticipated him in many ways, it was Justus Friedrich Carl Hecker by his 1832 study of the Black Death who changed the perceptions of historians by using mainly historical sources to create a vivid picture of the effects of this epidemic. ${ }^{13}$ In a vigorous and colourful account that Faye Getz has wittily called a "gothic epidemiology", Hecker argued for the supreme importance of the Black Death in changing medieval society. ${ }^{14}$ From Greenland to China, the whole organism of the world was in disorder, and the consequences lasted for long. Hecker wrote his powerful history in part in response to the advent of new epidemics and as a plea for the importance of the new epidemiology in modern medicine. His history quickly became authoritative, being translated immediately into English. This translation, along with other essays, was reprinted in 1844 by the Sydenham Society, a group of British doctors who wished to show the relevance of earlier writings and experiences to present-day medical concerns. ${ }^{15}$

Hecker's call was swiftly heard by other German colleagues. Julius Rosenbaum, one of his earliest readers, went so far as to declare the Black Death the turning point in human history. ${ }^{16}$ Heinrich Haeser included in his authoritative Lehrbuch der Geschichte der Medicin und der epidemischen Krankheiten a substantial section on the moral and social effects of the Black Death, prefaced by one of Hecker's most purple passages. ${ }^{17}$ Apart from this, only syphilis is treated in this way by Haeser, and none of the major epidemics in the

\footnotetext{
${ }^{11}$ Christian Gottfried Gruner, Nosologia historica ex monumentis medii aevi lecta animadversionibus historicis ac medicis illustrata, Jena, in Bibliopolio Academico, 1795; Kurt Polycarp Sprengel (ed.), Beiträge zur Geschichte der Medicin, Halle, Renger, 1794, pp. 36-116. For Gruner, see now Hans-Uwe Lammel, Klio und Hippokrates. Ein Liaison littéraire des 18. Jahrhunderts und die Folgen für die Wissenschaftskultur bis 1850 in Deutschland, Sudhoffs Archiv, Beiheft 55, Stuttgart, Franz Steiner, 2005, pp. 158-77, 198-200. For Sprengel, ibid., pp. 222-32, and 'Kurt Sprengel und die deutschsprachige Medizingeschichtsschreibung in der ersten Hälfte des 19. Jahrhunderts', in Andreas Frewer and Volcker Roelcke (eds), Die Institutionalisierung der Medizinhistoriographie: Entwicklungen vom 19. ins 20. Jahrhundert, Stuttgart, Franz Steiner, 2001, pp. 27-38; Alain Touwaide, 'Botanique et philologie; l'édition de Dioscoride de Kurt Spengel', in Danielle Gourevitch (ed.), Médecins érudits de Coray à Sigerist, Paris, De Boccard, 1995, pp. 25-44, with a bibliography on Sprengel, pp. 198-99.

${ }^{12}$ Sprengel (ed.), op. cit., note 11 above, p. 37. Sprengel's confessed motivation shows the difference in perspective between his generation and the developments in historical epidemiology after Hecker.

${ }^{13}$ Justus Friedrich Carl Hecker, Der schwarze Tod im vierzehnten Jahrhundert. Nach den Quellen für Ärzte und gebildete Nichtärzte bearbeitet, Berlin, F A Herbig, 1832. On Hecker, the most up-to-date account is in Lammel, op. cit., note 11 above, pp. 304-25.

${ }^{14}$ Faye Marie Getz, 'Black Death and the silver lining: meaning, continuity and revolutionary change in histories of medieval plague', J. Hist. Biol., 1991, 24: 265-89, oddly calling him Justin Hecker throughout. For the "gothic epidemiology", ibid., p. 279.

${ }^{15}$ Justus Friedrich Carl Hecker, The Black Death in the fourteenth century, trans. B G Babington, London, A Schloss, 1833; repr. as The epidemics of the Middle Ages, London, The Sydenham Society, 1844.

${ }^{16}$ Julius Rosenbaum, 'Die Epidemien als Beweise einer fortschreitenden physischen Entwicklung der Menschheit betrachtet. Eine Probevorlesung', in Johan Christian August Clarus, Justus Radius (eds), Beiträge zur praktischen Heilkunde mit vorzüglicher Berücksichtigung der medizinischen Geographie, Topographie und Epidemiologie, Leipzig, Fleischer, 1834-37, vol. 4, pp. 1-18, discussed by Lammel, op. cit., note 11 above, p. 156.

${ }^{17}$ Heinrich Haeser, Lehrbuch der Geschichte der Medicin und der epidemischen Krankheiten, Jena, Mauke, 1845. The work expanded with subsequent editions, 2nd ed., 2 vols, Jena, G Fischer, 1865; 3rd ed., Jena, G Fischer,
} 


\section{Vivian Nutton}

eighteenth or nineteenth century is discussed in terms of its wider impact on society. ${ }^{18}$ The Black Death also occupied a central position in the medico-historical publications of August Hirsch, who had in 1865 overseen a revised reprint of Hecker, and whose leading role in German epidemiology ensured for many years a close link between contemporary epidemiology and the history of medicine. ${ }^{19} \mathrm{He}$ was not alone in this. As late as 1882 , in the third, revised edition of his Lehrbuch, Haeser could reiterate that the past history of "plague", and particularly the Black Death, could not be neglected by any respectable doctor, because the descriptions of past epidemics offered a means of distinguishing different types of fevers. ${ }^{20}$ Contemporary epidemiology, at least as taught by Haeser, Hirsch, and English followers like Charles Creighton, still used the same categories and the same explanations for disease-climate, dirt, poor air, miasma, bad water, contagion-as their earlier predecessors. ${ }^{21}$ True, the researches of Pasteur held out the possibility of a precise identification of the "immediate" cause of various epidemic diseases, but Haeser's very formulation implied that there were other, and equally important, causal factors in play. ${ }^{22}$

The notion, vigorously espoused by Hecker, Haeser, and their followers, of the crucial significance of the Black Death brought with it two less happy consequences. The first, still visible today even in the most scrupulous of authors, was the use of the Black Death as a crucial divider. ${ }^{23}$ Before the Black Death, it was believed, medieval medicine and

1885. I have cited it from the third edition, vol. III, pp. 97-188. Haeser also devoted several pages to it in his Historisch-pathologische Untersuchungen, Dresden, Fleischer, 1839-1841, vol. I, pp. 110-35.

${ }^{18}$ For syphilis, and its "influence on social relations and medicine", Haeser, op. cit., note 17 above, vol. III, pp. 314-17.

${ }^{19}$ August Hirsch, Handbuch der historisch-geographischen Pathologie, 3 vols, Erlangen, Enke, 1859-64. He reprinted Hecker's studies on the Black Death and other epidemics as Die grossen Volkskrankheiten des Mittelalters. Historisch-pathologische Untersuchungen, Berlin, Enslin, 1865. Good studies of Hirsch's historical interests are lacking, despite Eugen Beck, 'Die Historisch-Geographische Pathologie von August Hirsch. Ein Beitrag aus dem 19. Jahrhundert zum Gestaltwandel der Krankheiten', Gesnerus, 1961, 18: 33-44, and Frank A Barrett, 'August Hirsch: as critic of, and contributor to, geographical medicine and medical geography', in Nicolaas A Rupke (ed.), Medical geography in historical perspective, Medical History, Suppl. 20, London, Wellcome Trust Centre for the History of Medicine at UCL, 2000, pp. 98-120.

${ }^{20}$ Haeser, op. cit., note 17 above, vol. III, p. 974.

${ }^{21}$ For Creighton, see the introduction to the reprint of his History of epidemics in Britain, 2 vols, London, Frank Cass, 1965 (originally Cambridge University Press, 1891-1894). Creighton was responsible for the English translation of Hirsch's Handbook of geographical and historical pathology, London, The New Sydenham Society, 1883-6.

${ }^{22}$ Haeser, op. cit., note 17 above, vol. III, p. 984. The final section, pp. 972-85, shows Haeser's difficulties in coming to terms with the new bacteriology. German doctors were very much divided, see Richard J Evans, Death in Hamburg, Harmondsworth, Penguin, 1990, pp. 231-43. For the explanatory categories of mid-nineteenth-century epidemiology, see Christopher Hamlin, 'Predisposing causes and public health in early nineteenth-century medical thought', Soc. Hist. Med., 1992, 5: 43-70, whose discussion of exclusively British sources applies also to their German contemporaries. The link between epidemiology and medical history was specifically declared in the subtitle to the journal Janus: Archives internationales pour l'Histoire de la Médecine et la Géographie médicale, 1896-1941: 1-45, which published the latest news on plague and proposed changes in entry requirements as well as historical articles. The sub-title was dropped when the journal resumed in 1957 as a purely historical publication.

${ }^{23}$ See, for example, Anna Foa, The Jews of Europe after the Black Death, Berkeley, University of California Press, 2000; Michael R McVaugh, Medicine before the plague: practitioners and their patients in the crown of Aragon 1285-1345, Cambridge University Press, 1993. The titles of two successive Cambridge conferences neatly mark the division: Luis García-Ballester, Roger French, Jon Arrizabalaga and Andrew Cunningham (eds), Practical medicine from Salerno to the Black Death, Cambridge University Press, 1994, and Roger French, 


\section{Introduction}

medieval society enjoyed a century or more of success. From the 1350 s onwards, society lost faith in organized medicine, a change mirrored in other aspects of society. That this is at best unproven has not prevented the continued denigration of the medicine of the late fourteenth and fifteenth centuries. ${ }^{24}$

More serious has been the, perhaps unwitting, concentration on the events of 1347-50 to the detriment of similar studies of later outbreaks. Compared with almost a hundred pages on the events of 1347-50, Haeser devoted less than ten to the epidemics of plague in the sixteenth century, ten to those of the seventeenth century, and thirteen to the eighteenth, despite the abundance of written material and the widespread nature of the recurrent epidemics. ${ }^{25}$ Not even Corradi's lengthy catalogue of plague outbreaks in Italy could alter the focus on the 1340s, and it was not until 1975, when Jean-Noël Biraben published the first volume of his Les hommes et la peste en France et dans les pays européens et méditerranéens, that one could easily get an overall view of the spread and frequency of later outbreaks. ${ }^{26}$ Of greater significance in introducing anglophone readers to the importance of these later outbreaks was the series of books on epidemic diseases in sixteenth- and seventeenth-century Italy by Carlo Cipolla, which combined magisterial brevity with effective story-telling. ${ }^{27} \mathrm{He}$ was followed by other historians who provided valuable surveys of plague over a long period from the 1340 s onwards in different regions. ${ }^{28}$

Jon Arrizabalaga, Andrew Cunningham and Luis García-Ballester (eds), Medicine from the Black Death to the French Disease, Aldershot, Ashgate, 1998.

${ }^{24}$ Complaints against doctors can be found at almost any time, and Petrarch's sallies against them should not be taken too seriously. There is, to my knowledge, no evidence for the desertion of physicians and surgeons for other healers as a result of the Black Death. The process of medicalization continued apace, and the doctors and surgeons themselves could argue that the survival of patients proved the value of their treatments, see Samuel K Cohn Jr, The Black Death transformed: disease and culture in early Renaissance Europe, London, Arnold, 2002, pp. 235-8, and, for the later example of Simone Simoni in his plague tract of 1576, see Vivian Nutton, "It's the patients' fault": Simone Simoni and the plague of Leipzig, 1575', Intellectual Hist. Rev., 2008, 81 (1): 5-13. But the effect of this belief on historians is neatly shown by the essays in French, et al. (eds), op. cit., note 23 above, which concentrate largely on the period before 1370 or after 1493 .

${ }^{25}$ Haeser, op. cit., note 17 above, vol. III, pp. 183-8, 348-56, 407-17, 459-63, 518-24, 588-91.

${ }^{26}$ Corradi, op. cit., note 8 above; Jean-Noël Biraben, Les hommes et la peste en France et dans les pays européens et méditerranéens, 2 vols, Paris, Mouton, 1975-1976.

${ }^{27}$ Carlo M Cipolla, Cristofano and the plague: a study of public health in the age of Galileo, London, Collins, 1973; Public health and the medical profession in the Renaissance, Cambridge University Press, 1976; Faith, reason and the plague: a Tuscan story of the seventeenth century, Brighton, Harvester Press, 1979; Fighting the plague in seventeenth-century Italy, Madison, University of Wisconsin Press, 1982; Miasmas and disease: public health and the environment in the pre-industrial age, New Haven, Yale University Press, 1992.

${ }^{28}$ Important studies in English since the 1970s include Michael W Dols, The Black Death in the Middle East, Princeton University Press, 1977; Richard J Palmer, 'The control of plague in Venice and Northern Italy, 1348-1600', unpublished PhD Dissertation, University of Kent at Canterbury, 1978; John Alexander, Bubonic plague in early modern Russia: public health and urban disaster, Baltimore, Johns Hopkins University Press, 1980; Paul Slack, The impact of plague on Tudor and Stuart England, London, Routledge and Kegan Paul, 1985; Ann G Carmichael, Plague and the poor in Renaissance Florence, Cambridge University Press, 1986; Giulia Calvi, Histories of a plague year: the social and the imaginary in baroque Florence, Berkeley and Los Angeles, University of California Press, 1989; Ole J Benedictow, Plague in the late medieval Nordic countries: epidemiological studies, Oslo, Middelalterforlaget, 1992; Edward A Eckert, The structure of plagues and pestilences in early modern Europe: central Europe, 1560-1640, Basle, Karger, 1996; A Lynn Martin, Plague? Jesuit accounts of epidemic disease in the sixteenth century, Kirksville, MO, The Sixteenth Century Journal Publications, 1996; Andrew Cunningham and Ole Peter Grell, The four horsemen of the Apocalypse: religion, war, famine and death in Reformation Europe, Cambridge University Press, 2000; William Naphy and Andrew Spicer, The Black Death: a history of plagues, Stroud, Tempus, 2000. 


\section{Vivian Nutton}

Yet, a few famous incidents apart, even today, as this volume itself shows, it is the events of a handful of years in the middle of the fourteenth century that attract greatest public attention. The very phrase, the Black Death, seems to set it apart from all other outbreaks. ${ }^{29}$

If in the mid and late nineteenth century historians of the Black Death could still see themselves as contributing to the understanding of contemporary outbreaks of a disease they called "plague" or "pest", Alexandre Yersin's discovery at Hong Kong in 1894 of the bacillus he knew as Pasteurella pestis changed all that. ${ }^{30}$ As Andrew Cunningham emphasizes, from now on plague was a specific entity, a specific bacillus, that could not be confused with any other agent. ${ }^{31}$ Even if one does not go as far as Cunningham would wish and deny the title of plague to earlier epidemics, there is no doubt that what was understood by that appellation before 1894 was very different from what came after. Henceforth, plague was a disease caused by Pasteurella (later Yersinia) pestis, and, after Paul-Louis Simond's researches in India, spread by fleas. ${ }^{32}$ Other manifestations of plague, such as the rare pneumonic variety, in which the disease is spread directly from sufferer to sufferer by the air, were consequences of a primary outbreak of infection by fleas. ${ }^{33}$ The experiences of researchers in China, Manchuria and India only confirmed the general validity of those conclusions, and transformed historians' understanding of its earlier appearances in history. Whereas formerly physicians were invited to consider historical accounts of earlier epidemics as an aid in their practice, now the medical definition of, and modern experiences with, plague in various parts of the world were referred back to throw light on, if not to determine, historians' descriptions of plague. A distinguished line of plague experts, from E H Hankin, Wu Lien-Teh, and Fabian Hirst to J F D Shrewsbury, used their understanding of contemporary plague to impose the medical model of modern plague on the information provided by past chroniclers. ${ }^{34}$ And, for the most part, historians have

\footnotetext{
${ }^{29}$ The phrase is generally used to refer to the events of the $1340 \mathrm{~s}$, or the later fourteenth century as well, and may even include the early fifteenth century, and thus sets this outbreak off from later recurrences. The ambiguity arises in part from the fact that the name was not applied to this epidemic until the seventeenth century, and it did not enter general use until Hecker. For contemporary names, see Cohn, op. cit., note 24 above, pp. 104-5.

${ }^{30}$ The story of the identification of Pasteurella pestis by Yersin and his rivalry with Shibasaburo Kitasato is told with gusto by Edward Marriott, The plague race: a tale of fear, science and heroism, London, Picador, 2002, and, more soberly and with greater attention to later developments, by Cohn, op. cit., note 24 above, pp. 7-24. The standard biography of Yersin is by Henri H Mollaret and Jacqueline Brossollet, Alexandre Yersin, le vainqueur de la peste, Paris, Fayard, 1985.

${ }^{31}$ Andrew Cunningham, 'Transforming plague: the laboratory and the identify of infectious disease', in Andrew Cunningham and Perry Williams (eds), The laboratory revolution in medicine, Cambridge University Press, 1992, pp. 209-44.

${ }^{32}$ For Simond, and the debates over his theory, see Frédérique Audoin-Rouzeau, Les Chemins de la peste: le rat, la puce et l' homme, Paris, Tallandier, 2007, pp. 34-57.

${ }^{33}$ For the debate about pneumonic plague and the even more vexed possibility of human to human transmission via the human flea, Pulex irritans, see Cohn, op. cit., note 24 above, pp. 20-23, and Audoin-Rouzeau, op. cit., note 32 above, pp. 115-56, 169-210, 421-80.

${ }^{34}$ E H Hankin, 'On the epidemiology of plague', J. Hygiene, 1905, 5: 48-83; Wu Lien-Teh, A treatise on pneumonic plague, Geneva, League of Nations, 1926; L Fabian Hirst, The conquest of plague: a study of the evolution of epidemiology, Oxford, Clarendon Press, 1953; Robert Pollitzer, Plague, Geneva, World Health Organization, 1954; J F D Shrewsbury, A history of bubonic plague in the British Isles, Cambridge University Press, 1970.
} 


\section{Introduction}

been glad to follow them. ${ }^{35}$ After all, if one knows the parameters of a disease, one might be able to draw conclusions about how the disease may have worked in the past. ${ }^{36}$

For their part, historians concentrated on refining Hecker's nearly apocalyptic vision of the development and consequences of the Black Death. Working on local sources, they could show that some of his novelties, like the procession of Flagellants, were not new, others, like the persecution of the Jews, were more localized, and some of his economic and social changes, notably population decline and rising prices, were already appearing from the early years of the fourteenth century. The arrival of epidemic disease exacerbated these trends, but it did not create them. ${ }^{37}$ The most influential of all modern histories of the pandemic of the fourteenth century, Philip Ziegler's The Black Death, goes beyond Hecker mainly in the additional literary sources that he could draw upon to produce a powerful and elegant narrative. ${ }^{38} \mathrm{He}$ assimilates new discoveries in local archives, places them in a broad European perspective, and sweeps the reader along in a confident survey that combines insight with human interest.

But the many reprintings of this deservedly classic description disguise its greatest weakness. A brilliant refashioning of mainly literary sources, it was written just as important new material was becoming available thanks to computers and the arrival of the demographers. General perceptions by contemporary chroniclers could now be checked against other more extensive official and semi-official documentation. Lists of plague victims had been used before, for example in Frank Wilson's study of Tudor London, but these lists could not compare with the detail provided by the registers of the burials from churches or, particularly in Italy, confraternities. ${ }^{39}$ It was now possible to aggregate large bodies of statistical information from which wider patterns could be deduced. From the 1960s onwards, medical epidemiologists and historical demographers worked with the same methodologies to answer similar questions about disease. ${ }^{40}$ One could now, it was

\footnotetext{
${ }^{35}$ This approach is adopted by all the historians cited above in notes 28 and 60 , and, more recently, by Ole J Benedictow, The Black Death, 1346-1353: the complete history, Woodbridge, Boydell Press, 2004; and John Kelly, The great mortality: an intimate history of the Black Death, the most devastating plague of all time, New York, Harper Collins, 2005. Audoin-Rouzeau, a specialist in rat archaeology, also privileges the medical evidence, although taking a more independent line.

36 "May have". Or "should"? Or "would"? The subtle modalities of the English verb carry different connotations as to the validity of the initial hypothesis.

${ }^{37} \mathrm{Getz}$, op. cit., note 14 above, briefly surveys these revisions by historians, singling out Elizabeth Carpentier, Une ville devant la peste: Orvieto et la peste noire de 1348, Paris, S.E.V.P.E.N., 1962, as an early example of the importance of local studies. For warnings against over-interpreting the consequences of the Black Death, see Bruce Campbell (ed.), Before the Black Death: studies in the "crisis" of the early fourteenth century, Manchester University Press, 1991; David Herlihy, The Black Death and the transformation of the west, ed. Samuel K Cohn Jr, Cambridge, MA, Harvard University Press, 1997.

${ }^{38}$ Philip Ziegler, The Black Death, first published London, Collins, 1969, and many times reprinted. It enjoyed the dubious honour of being heavily plagiarized by Robert S Gottfried, The Black Death: natural and human disaster in medieval Europe, London, Hale, 1983.

${ }^{39}$ F P Wilson, The plague in Shakespeare's London, Oxford, Clarendon Press, 1927. Early studies by historical demographers include: John Hatcher, Plague, population, and the English economy, 1348-1530, London, Macmillan, 1977; Robert S Gottfried, Epidemic disease in fifteenth-century England: the medieval response and its demographic consequences, Leicester University Press, 1978; and, for Italy, Carmichael, op. cit., note 28 above.

${ }^{40}$ See, for example, Mary J Dobson, Contours of death and disease in early modern England, Cambridge University Press, 1997. Susan Scott and Christopher Duncan, Biology of plagues: evidence from historical populations, Cambridge University Press, 2001, is a collaborative work between a medical epidemiologist and a demographer.
} 


\section{Vivian Nutton}

hoped, distinguish the different patterns of disease by seasonality or mortality, and once again use the records of the past to throw light on present epidemiological concerns. Conversely, patterns discovered by epidemiologists in the field could be used by historians to confirm the existence of diseases in the past, particularly when, like many viral diseases, they left no distinguishing features on bones and hard tissue.

While in general seeming to confirm the notions of earlier historians, not least in the severity and frequency of outbreaks, the evidence of demography also threw up anomalies and problems. If, as was thought, the Black Death spread largely along trade routes, why were some major trading cities, notably Milan, almost untouched? And why were many cities of Central Europe, such as Würzburg, left unvisited for several years despite being in contact, by road and river, with infected areas? ${ }^{41}$ There was a search for reservoirs of infection, where the flea, Xenopsylla cheopis, might lurk among the rodent population, specifically that of the black rat, and several were found, most notably on the steppes of Central Asia, an area conveniently lacking historical texts wherewith to confirm or refute any hypothesis. ${ }^{42}$ The more data demographers assembled, the more anomalies they found between the behaviour of Yersinia pestis as observed in the twentieth century and as apparently recorded six centuries earlier. Some difficulties could be easily explained away. Early observers of the Black Death need not have recorded everything that a modern scientist would, either through ignorance or a failure to observe, or because some features were so common as not to need mention. Just as Galen had lamented Thucydides' limitations, so historians could bewail the omissions of medieval authors unfamiliar with modern diagnostic methods. And they could also fill in the gaps in one author with material taken from another.

But what might be termed the anomalies of positive evidence proved more difficult to explain. In particular, the spread of the epidemic of the 1340s was somewhat different climatically, much more extensive in area, and moving at a much faster rate than any recorded epidemic of bubonic plague in the modern period. The epidemiological maps of George Christakos and his group demonstrate beyond doubt two very different patterns. ${ }^{43}$ Even in a crowded country like India or China, with swifter methods of transport and a greater variety of contacts, modern plague moves far more slowly than its medieval equivalent, and infects far fewer individuals. Person to person infection in the form of pneumonic plague is relatively rare, even if it continues to carry a high level of morbidity and mortality. Such outbreaks are also relatively short-lived. Other researchers wondered about the effects of climate changes, and the existence of a sufficient number of rodent hosts. Still others, most notably Frédérique Audoin-Rouzeau, pointed out that Xenopsyllus cheopis, the flea vector in the so-called third pandemic, is rare in temperate Europe, where another flea also capable of transmitting the bacillus, Nosopsyllus fasciatus, predominates. ${ }^{44}$

\footnotetext{
${ }^{41}$ Stuart Jenks, 'The Black Death and Würzburg: Michele de Leone's reaction in context', PhD Dissertation, Yale University, 1976.

${ }^{42}$ In the 1980s, I saw a TV programme on the Black Death that located its source on the shores of, and even in, Issyk Kul, a lake in Kirghizstan, thereby actualizing the metaphor of reservoir.

${ }^{43}$ George Christakos, Ricardo A Olea, Marc L Serre, Hwa-Lung Yu, Lin-Lin Wang, Interdisciplinary public health reasoning and epidemic modelling: the case of Black Death, Berlin and New York, Springer, 2005; George Christakos, Ricardo A Olea, Hwa-Lung Yu, 'Recent results on the spatiotemporal modelling and comparative analysis of Black Death and bubonic plague epidemics', Public Health, 2007, 121 (9): 700-20.

${ }^{44}$ Audoin-Rouzeau, op. cit., note 32 above, pp. 81-92, although she suggests a potentially similar pattern of infestation to that of Xenopsyllus cheopis.
} 


\section{Introduction}

The consensus about Yersinia pestis as the cause of the Black Death came under attack from both historians and biologists. The first to question the consensus was Graham Twigg, a biologist, who doubted that the pattern of insect vectors could have been the same. ${ }^{45} \mathrm{He}$ was followed by the Liverpool pairing of Susan Scott and Christopher Duncan, whose long experience with the patterns of modern epidemic disease caused them to doubt that the majority of deaths in the pre-modern period attributed to Yersinia pestis could have been so, although they allowed that, in some instances, most notably the plague of Marseilles in 1720-2, some such infection was present. ${ }^{46}$ Among demographers, David Herlihy, who had developed a major database on the population of medieval Florence, expressed his doubts on the identification of Yersinia pestis, as well as his more serious concerns about the supposed consequences of the arrival of the disease, in a posthumous publication in $1997 .{ }^{47}$ Samuel Cohn Jr, who had edited Herlihy's posthumous volume, continued the attack on the traditional theory, basing himself on a major rereading of the medieval texts. ${ }^{48}$

Not everyone was convinced, pointing, among other things, to the very different solutions offered to the identification of the disease, anthrax (Twigg), a septicaemic infection (Scott and Duncan), and an as yet unidentified illness that may no longer exist (Cohn). ${ }^{49}$ The sceptics' opponents could also point to new information that appeared conclusively to confirm the traditional viewpoint - the evidence of archaeology and DNA. ${ }^{50}$

The archaeological evidence for plague is remarkably scanty, considering its recurrence over the centuries in western Europe. ${ }^{51}$ Although it is well known that bodies were regularly disposed of in large plague pits, no such site has ever been identified archaeologically. While part of the explanation may lie in the absence of distinguishing signs of plague on the skeleton, and in the possibility that many plague corpses were burnt, it is still curious that the modern expansion of cities like Rome or Florence has not revealed such plague pits some way beyond the walls of the old city but now inside the urban sprawl. The fact that, if found, mass burials might be difficult to date, given the frequency of outbreaks, is less important than the absence of any secure identification of such a large plague site.

Smaller sites, however, have been identified, and in 1998 and again in 2000, a French team led by Didier Raoult announced that they had found Yersinia pestis DNA at medieval Montpellier and at eighteenth-century Marseilles. ${ }^{52}$ Their findings were roundly criticized, since at that time no other group had succeeded in replicating their findings. ${ }^{53}$ The same

\footnotetext{
${ }^{45}$ Graham Twigg, The Black Death: a biological reappraisal, London, Batsford, 1984. (The adjective is crucial.)

${ }^{46}$ Susan Scott and Christopher Duncan, Return of the Black Death: the world's greatest serial killer, Chichester, Wiley, 2004. Their conclusions, which went back to Scott's doctoral thesis on mortality in Penrith, were adumbrated in their Biology of plagues.

${ }^{47}$ Herlihy, op. cit., note 37 above.

${ }^{48}$ Cohn, op. cit., note 24 above.

${ }^{49}$ Other suggestions include Ebola virus, and other viral infections. For Cohn's response, see below, p. 100.

${ }^{50}$ Kelly, op. cit., note 35 above, p. 300, concludes that the DNA evidence is "more trustworthy".

${ }^{51}$ Cf. Antoine, below. Note also William White, "Excavations at St. Mary Spital: burial of the "sick poore" of medieval London, the evidence of illness and hospital treatment', in Barbara S Bowers (ed.), The medieval hospital and medical practice, Aldershot, Ashgate, 2007, p. 61, for a possible other London site.

${ }^{52}$ Didier Raoult, Gérard Aboudharam, Eric Crubézy, Georges Larrouy, Bertrand Ludes, Michel Drancourt, 'Molecular identification by "Suicide PCR" of Yersinia Pestis as the agent of medieval Black Death', Proc. Natl. Acad. Sci. USA, 2000,97 (23): 12800-803.

${ }^{53}$ Michael McCormick, 'Toward a molecular history of the Justinianic pandemic', in Lester K Little (ed.), Plague and the end of Antiquity: the pandemic of 541-750, Cambridge University Press, 2007, pp. 290-312, at p. 295.
} 


\section{Vivian Nutton}

group has even more recently announced that it has found similar traces in a new and much earlier site, at Vienne, datable to the sixth or seventh century AD, which would link the plague of Justinian to much later outbreaks. ${ }^{54}$ But problems still remain, and the conclusions of this group have not yet met with the unequivocal satisfaction of all the scientists involved with DNA investigation, let alone historians. At best, there is general agreement that Yersinia pestis was present in the Marseilles plague of 1720, and that it may be found elsewhere, with debate centring on the reasons for its near total absence. The doubters argue that this is only to be expected, since the disease was never there in the first place, and that the continued negative results of other experienced teams searching for just this type of evidence strengthens the case of the sceptics more and more. Their opponents, stressing that the absence of evidence is not the same as evidence of absence, pin their hopes firmly on the development of new techniques and on better sites. What cannot be denied is that it is extremely difficult to obtain Yersinia pestis DNA from bodies compared with traces of many other disease agents. The DNA degrades easily, and can easily be confused. Obtaining uncontaminated samples is difficult, even though techniques are improving and appropriate protocols are becoming established across the scientific community. ${ }^{55}$

This was the message delivered by Robert Sallares and Michael McCormick at the Rome conference on the plague of Justinian, and by Robert Sallares and Helen Donoghue in verbal comments at the London conference. ${ }^{56}$ But their general optimism that more and more evidence of Yersinia pestis DNA will be found on sites closely linked to the events of the 1340s may, if confirmed, settle one question only, and arguably not the most important one historically. Scott and Duncan provocatively label the identification problems of DNA irrelevant to their own conclusion. ${ }^{57}$ Since in their view the agent responsible for the Black Death was something else entirely, they see no reason to bother with a search for something that played no part, or, their fallback position, was a subsidiary infection, present but only at a very low level. But even those willing to accept the traditional view must spell out why the identification matters to them, and justify the value they ascribe to it. ${ }^{58}$

The Rome conference just mentioned had a specific purpose, to bring to wider notice an earlier infestation of plague that had been downplayed by historians. ${ }^{59}$ Although it spread across the Middle East and Europe in 541, and according to contemporaries caused a severe loss of life as well as social and political unrest, it had attracted much less attention from scholars. In part, this was because it did not remain endemic in Europe to anything like the same extent that it did in the Middle East, and hence was not seen as an important part of European, and particularly western European, history. More important, in the nineteenth century, as can be seen by comparing Haeser's account with those in the Rome volume, many of the sources used by today's historians were either unavailable

\footnotetext{
${ }^{54}$ Michel Drancourt, Michel Signoli, La Vu Dang, Bruno Bizot, Véronique Roux, Stéfan Tzortzis, Didier Raoult, 'Yersinia pestis Orientalis in remains of ancient plague patients', Emerg. Infect. Dis., 2007, 13 (2): 332-3.

${ }^{55} \mathrm{Cf}$. Antoine, below, pp. $110 \mathrm{ff}$.

${ }^{56}$ Robert Sallares, 'Ecology, evolution and epidemiology of plague', and McCormick, 'Molecular history', in Little (ed.), op. cit., note 53 above, pp. 231-89, 290-312. I am grateful to Daniel Antoine and Helen Donoghue for their advice on recent developments.

${ }^{57}$ Scott and Duncan, op. cit., note 46 above, pp. 185-90, "a red herring".

${ }^{58}$ Jo N Hays, 'Historians and epidemics: simple questions, complex answers', in Little (ed.), op. cit., note 53 above, pp. 33-56, raises the question with a degree of clarity that his answer then confuses.

${ }^{59}$ Little (ed.) op. cit., note 53 above, esp. Lester K Little, 'Life and afterlife of the first plague pandemic', pp. 3-32.
} 


\section{Introduction}

or unfamiliar to western European scholars. Material from the Arab world, whether historical, medical or even archival, still remained unexamined in libraries, and the number of western scholars capable of reading them in the original was very few. The burgeoning of Arabic studies in the last half century has changed all that, and we now have studies that can rival in detail those devoted to the Black Death. ${ }^{60}$ That the plague of Justinian and the Black Death could be linked by the same deadly agent thus mattered in promoting the importance of the earlier outbreak. It also provided further justification for medieval Latin authors in drawing upon theories and remedies for plague drawn up and preserved by Arabic authors. Both groups faced the same threat, and avowedly successful remedies could, and should, be employed in a renewed outbreak. But, until now, the plague of Justinian still has hardly been considered in studies of the Black Death and later outbreaks. At best it has merited a few passing comments, but often the long gap between the ending of the one and the onset of the other has seemed sufficient grounds for silence. That silence should no longer be maintained, but the nature of the link between the two pandemics still remains questionable. That experiences in one pandemic can throw light on the other is almost a platitude, in that both were societies facing an immense, and to them, novel threat. Whether they can be linked more closely depends on the weight that is put on the molecular history of Yersinia pestis, and the use that historians wish to make of that information.

Arguments for the importance of the identification of Yersinia pestis as the major infective agent in 1345-51 are twofold. Understanding the behaviour of Yersinia pestis today, it is suggested, can serve as a guide to understanding what happened in previous epidemics, and, alternatively, the detailed evidence of those epidemics over the four centuries that followed can then be used to throw light on present manifestations of the disease. Neither argument is entirely legitimate, and one must take the utmost care not to proceed along a path that is ultimately circular.

There can be no doubt that historians are far more comfortable with a named disease than with an agent $\mathrm{X}$, and that, as with the plague of Thucydides, a disputed, or undefined, cause leads naturally to a proliferation of attempts to solve the problem. There is also the hope that one can use the clinical symptoms of the pathogen, once identified, to understand how past sufferers and observers reacted. ${ }^{61}$ Some would go even further, and use what is known as the behaviour of the disease today as a means of judging the actions of those in the past. Discussions of the value of bonfires, protective clothing or killing cats and dogs thus proceed in the knowledge that the main vector of Yersinia pestis is the flea. ${ }^{62}$ Or perhaps of greater relevance to the questions posed by historians, the by now well documented, pattern

\footnotetext{
${ }^{60}$ For the oriental sources, see Michael G Morony, " "For whom does the writer write?" The first bubonic plague pandemic according to Syriac sources', in Little (ed.), op. cit., note 53 above, pp. 59-86. Lawrence I Conrad's PhD Dissertation, 'Plague in the early medieval Near East', Princeton University, 1981, has never been published, but his conclusions have appeared in many articles, e.g., 'Arabic plague chronologies and treatises: social and historical factors in the formation of a literary genre', Studia Islamica, 1981, 54: 51-93; 'Die Pest und ihr soziales Umfeld im nahen Osten des frühen Mittealters', Der Islam, 1996, 73: 81-112; 'Epidemic disease in Central Syria in the late sixth century: some new insights from the verse of Hassān ibn Thābit', Byzantine and Modern Greek Studies, 1994, 18: 12-58. The Arabic sources for the Black Death were similarly neglected until Dols, op. cit., note 28 above.

${ }^{61}$ Cf. Hays, op. cit., note 58 above, p. 52, although some of his speculations depend on disregarding his own warnings.

${ }^{62}$ Audoin-Rouzeau, op. cit., note 32 above, is a vigorous plea for attention to the role of the animal vectors.
} 


\section{Vivian Nutton}

of the sudden disappearance of bubonic plague today, and its reappearance often after several decades, adds a new perspective to discussions of why plague ended suddenly at different times in different regions, even though there might appear to be no clear reason why, say, even after the fire of London in 1666, the city itself could not have been reinfected by flea-bearing rodents from other areas. ${ }^{63}$ Yet, at the same time, as Samuel Cohn has argued in his book and in this volume, there are also very many differences, not least in patterns of morbidity and mortality, that place obstacles in the way of any easy correlation of the behaviour of modern and medieval plague. DNA analysis may throw some light on this problem, but it will not resolve it entirely.

All observers today agree that bubonic plague is among the easiest of diseases to identify, and modern plague experts find no difficulty in instant diagnosis. Nor did doctors in the past. A sixteenth-century physician, like Simone Simoni or Girolamo Mercuriale, felt extremely confident that he could tell if a person was suffering from plague, and that the epidemic with which he was dealing was exactly similar to the preceding one, and the one before that. ${ }^{64}$ The conviction of doctors that they were treating the same disease repeatedly over a long period of time is an argument in favour of those who wish to use the evidence of later epidemics to illuminate earlier ones. Even when, as with Mercuriale and his colleagues in 1576, there was a disagreement as to whether the plague in Venice was true plague or merely a plague-like fever-a decision with important social and economic consequences - all parties agreed ultimately on the symptoms that constituted plague. ${ }^{65}$ But this concurrence only makes more apparent the divergences from modern plague that do occur, and should impose a considerable caution on those who wish to use modern evidence to build up a picture of what it was like to suffer plague in the Middle Ages and Early Modern Europe. Indeed, one might argue that the identification of the agent of the Black Death with Yersinia pestis adds very little to what the historian could gain from the sources themselves. Where they agree with modern descriptions, the identification is unnecessary: where they do not, the identification is unhelpful and potentially misleading.

The unravelling of the DNA of Yersinia pestis has added new complications to the story, not least because of a renewed interaction of hypotheses between historians and scientists. So, for instance, the discovery that some humans appear to be less susceptible to HIV and plague because of their inheritance of a specific allele has suggested that the diminishing virulence of plague is due to the increased resistance of the surviving population as the percentage of the genetically favoured rises. This theory, based on a small human sample, seems unlikely, especially if it is argued that in 1345 only a tiny fraction of the European population possessed the relevant allele. Not only would the subsequent rate of reproduction have to be remarkably high, but a different explanation would have to be found for the disappearance of the Justinianic plague, if that too is accepted as bubonic. ${ }^{66}$

\footnotetext{
${ }^{63}$ A Lloyd Moote and Dorothy C Moote, The Great Plague: the story of London's most deadly year, Baltimore, Johns Hopkins University Press, 2004.

${ }^{64}$ Nutton, op. cit., note 9 above.

${ }^{65}$ Palmer, op. cit., note 9 above.

${ }^{66}$ Alison P Galvani and Montgomery Slatkin, 'Evaluating plague and smallpox as historical selective pressures from the CCR5-Ä32HIV-resistance allele', Proc. Natl. Acad. Sci. USA, 2003, 100 (25): 15276-9. The authors curiously assume that the Black Death only affected Europe, and hence that this explains the prevalence of this gene in Europeans. Cf. also Sallares, op. cit., note 56 above, p. 289.
} 


\section{Introduction}

Such an explanation was indeed proposed in the 1950s by Devignat, who suggested that there were three major groupings of strains (biovars) of Yersinia pestis, which he labelled "antiqua", "mediaevalis", and "orientalis". ${ }^{67}$ Yersinia pestis itself seems to have developed, no more than 20,000 years ago, out of Yersinia pseudotuberculosis, which today is responsible for a mild and short-lasting enteric disease in humans. ${ }^{68}$ Devignat distinguished his three biovars by their ability to ferment glycerol and to reduce nitrates to nitrites, arguing that the strain that still possessed both functions must be the oldest. His observations remain valid, but his identification of the historical appearance of his three types is fraught with difficulty. His supposition was that antiqua developed in Central Asia, and passed along trade routes to Central Africa, whence it spread back to the Mediterranean world as the plague of Justinian. Modern DNA analysis confirms the presence of this strain in Central Asia and, apparently at a slightly later date, in Africa. Devignat then associated the second biovar with the Black Death, hence its name, mediaevalis, and the third with the great pandemic of the nineteenth century, hence orientalis. The differences between the biovars would, in Devignat's theory, be enough to explain the differences between the patterns recorded by historians at the time. This is a seductive hypothesis, and is widely accepted. ${ }^{69}$ Historians' acceptance of Yersinia pestis as the agent of the Black Death thus becomes a means of distinguishing between two different forms of the pathogen, and, more importantly, of providing a date for the mutation, or mutations.

This is an unconvincing strategy. To credit the crucial mutation in one of the biovars, themselves supposedly stable, with the main responsibility for a pandemic is to neglect a whole range of other factors, which, in their turn, may have triggered the pandemic. ${ }^{70}$ It is a simplistic explanation, and one that the recent discoveries of the French team have excluded. Their investigations into the DNA recovered from three sites over a millennium apart are said to reveal the same strain in all of them, that of the orientalis biovar. ${ }^{71}$ At the very least, they show that that mutation took place many centuries before Devignat supposed, and that orientalis is likely to have been present in Europe throughout the intervening period. The Marseilles material, which is the most widely accepted, does not differ from that commonly found today, and one cannot then use the evidence of apparently different patterns of behaviour recorded historically to posit a different strain of Yersinia pestis. Of course, it would still be possible to imagine different biovars coexisting, but that is a desperate solution-and one that the supporters of the theory of Yersinia pestis may not wish to countenance.

\footnotetext{
${ }^{67}$ R Devignat, 'Variétés de l'espèce Pasteurella pestis: nouvelle hypothèse', Bull. World Health Organ., 1951, 4: 247-63; idem, 'La peste antique du Congo belge dans le cadre de l'histoire et de la géographie', Mémoires de l'Institut Royal Colonial Belge, 1953, 23: 1-47.

${ }^{68}$ Sallares, op. cit., note 56 above, pp. 246-50; Carniel, below, p. 120.

${ }^{69} \mathrm{Cf}$. the slightly different formulations of Sallares, op. cit., note 56 above, pp. $250-51$, and McCormick, op. cit., note 53 above, pp. 303-6. The latter shows clearly how historians' preconceptions react with those of scientists, and vice-versa. But note the protest against Devignat by Wendy Orent, Plague, New York, Free Press, 2004, pp. 58-9, suggesting that his classifications are not the most important ones, as well as the qualifications by Carmichael, below, p. 17.

${ }^{70}$ McCormick, op. cit., note 53 above, p. 306, draws attention to the frequency with which Yersinia pestis produces mutations, but also accepts the stability of Devignat's three biovars. The non-scientist may wonder whether this is not trying to have one's cake and eat it.

${ }^{71}$ Above, note 54 .
} 


\section{Vivian Nutton}

The papers in this volume were written by sceptics as well as believers in the theory that the infective agent of the Black Death was Yersinia pestis, spread primarily by rat fleas. The keynote speakers were asked to consider the problems raised by the different types of evidence with which they were most familiar.

Ann Carmichael bases herself largely on the north Italian evidence to describe what contemporaries saw as a universal pestilence, afflicting the whole earth. They continued to use the same words, pestilentia and peste, that they had used before to designate outbreaks of epidemic disease, while at the same time sensing that what they were encountering was something distinctive from other epidemics. They were having to adjust their traditional categories of explanation to fit what they believed they were observing for the first time. In particular, they had to accommodate their individual local situations to what they also associated with a universal epidemic, with its atmospheric and religious explanations, a situation that became more acute after the Jubilee of 1350 allowed its participants to compare experiences from around Europe.

In the second half of her paper, Professor Carmichael looks at the ways in which descriptions of plague changed in the light of later, repeated outbreaks over the next century and more. They were seen as renewed outbreaks, not continuations of what had occurred the previous year, and no one expressed concern at the plague's long duration or its continuation elsewhere. Nor, despite an overlap of terms, do doctors appear to have reached unified and precise clinical criteria for identifying the disease, even its most spectacular buboes. Instead, they often emphasized the speed with which patients died, a fact that also excused their inability to cure the sick, for its powerful onslaught gave them no time for their remedies to work. (And, one might add, the drugs necessary to defeat the disease as soon as its attack had begun were, by definition, themselves going to be powerful, and hence potentially harmful to the patient as well as his or her disease.) Furthermore, the renewed outbreaks, indeed pandemics, of medieval plague brought to an end any comforting assumptions that contemporaries might have had that the outbreak of 1348 was unique. It is no coincidence that the first concerted efforts to restrict the spread of plague through the interruption of trade and travel developed only after two or three major visitations.

Lars Walløe demonstrates the continuities in plague treatises down to the nineteenth century. Particularly in northern Europe, often neglected by historians more familiar with material from Italy or England, detailed descriptions of the symptoms of disease by careful observers offer a strong case for an identical agent at work, or, at any rate, one whose manifestations remained largely constant over several centuries. He argues that Yersin, Kitasato, and their contemporaries were familiar with a long series of descriptions of plague, and saw no problem in identifying what they had found on the basis of earlier work on plague. As well as pointing towards clinical similarities between medieval and modern descriptions, he discusses the problem of immunity to plague in the light of recent studies.

His argument is modified in a brief comment by Kay Peter Jankrift, who draws attention to a tendency of medieval historians to take over the language and explanation of epidemic diseases from their predecessors. He shows how a description of a local outbreak of perhaps St Anthony's fire in Lorraine became in Heinrich of Herford three hundred years later a worldwide outbreak. In its turn, Heinrich's description was transferred to a specifically local outbreak within Westphalia. As both he and Ann Carmichael show, one 


\section{Introduction}

of the tasks of the historian in examining the many descriptions of plague and epidemic disease is to distinguish what is purely local from more general phenomena.

A different approach is taken by Samuel Cohn, who examines the epidemiological evidence as presented by both modern students of the disease and the medieval observers. His argument takes seriously the extent to which the doctors and chroniclers of the time were capable observers, refusing to attribute discrepancies between medieval and modern data to the frailties of our predecessors. His chapter here goes beyond his formulations in his earlier book, both by clarifying the most significant areas of debate, and by discussing the consequences for the historian, should Yersinia pestis be shown to have been present in 1348. There are clearer links between the historical accounts of the Justinianic plague and those of the Black Death than there are between them and modern manifestations of plague, and historians (and scientists) will need to work together to explain the change between the second and third pandemics.

Daniel Antoine's paper, which develops out of his work on the London Royal Mint site, sets out the difficulties inherent in locating and interpreting the archaeological evidence. Although the greatest, for reasons already outlined above, lies in the actual recovery of DNA from the teeth of the dead, there are many others. The site itself may hamper recovery, and the numbers of graves may not be enough to allow for proper sampling. Even if plague DNA has been recovered, a conclusion on which he believes the jury still to be out, this does not mean that it is the only factor involved. The presence of other diseases, and malnutrition, may also play significant roles in an epidemic.

The short final paper, by Elisabeth Carniel, perhaps the most experienced researcher into modern plague, summarizes what the majority of scientists today believe about plague and Yersinia pestis. It is less an argument than an illustration of the problems facing a historian in trying to understand and analyse an earlier disease without the benefit of modern diagnostic methods. Among the points she raises are the possibility that the human flea, Pulex irritans, may have played a larger role than previously suspected, as well as the enormous range of climates and habitats where plague is found today. In some areas, more females than males are affected, in others the reverse. Adults and adolescents are often seen as at greatest risk, yet in Madagascar and Brazil the infection is most often found in children.

The vigorous discussions that followed the original presentations revealed continuing divisions between the speakers and their audience, but also several clear themes that were accepted by all the writers. First is the sheer difficulty involved in collecting and assessing the evidence. Not only is it extremely hard to extract DNA from appropriate bodies, but the more medieval sources one reads, the less coherent the story becomes. Nonetheless, the descriptions of the Black Death are generally in line with what followed, and one would be hard pressed to distinguish between the events of the 1340s and those of the 1570s, although one must always be aware of the tralatician nature of some of the words used and incidents described, as Dr Jankrift warns. Secondly, modern plague in its departures and reappearances still presents a problem of explanation for modern doctors and scientists. Historical evidence may help, but attempts to determine why a particular plague epidemic came to an end in the past may be frustrated by the knowledge of the vagaries of modern plague. Thirdly, the greatest problem in the identification of medieval plague with Yersinia pestis remains the pattern of morbidity, mortality, and speed of spread, which 


\section{Vivian Nutton}

differs considerably from that of modern plague, and occurred at a time when transport was much slower. (The speed of rat infection needs also to be taken into consideration, as Audoin-Rouzeau insists. ${ }^{72}$ ) What weight to put on this difference, and how to explain it, varies from scholar to scholar-another disease, a combination of diseases, difference in receptivity of the host, human and animal—but explanations in terms of a major mutation, a new biovar, in the bacillus itself, along the lines proposed by Devignat, seem now to be excluded. ${ }^{73}$ That modern bubonic plague occurs in a variety of very diverse habitats, plain and mountain, coast and interior, and in a variety of climates, with a varied demographic pattern, only complicates the picture.

Yersinia DNA may have been found in late-antique and medieval sites, but this discovery of itself it does not remove this problem, which is common both to sceptics and believers. Even if it is accepted that climatic changes can have an effect on the behaviour of Yersinia pestis, and that such a change may have triggered the Black Death-a claim that some would dispute - this still does not explain why the bacillus continued to behave in the same way over a long period and over many areas, and why these changes no longer apply in the same way today. ${ }^{74}$ If Yersinia pestis was the biological agent of the Black Death, as is still on balance the most likely explanation, its behaviour then, and for centuries afterwards, differed at times considerably from what has been observed over the last century and more. The symptoms of plague are recognizably the same, but its epidemiology and demographics are clearly distinct.

Finally, all participants in the conference and the authors of these papers emphasized the importance of interdisciplinarity. But that does not simply mean taking over the findings of one group and applying them to another. What became clear was the element of provisionality in all the papers delivered. This makes it even more important to ensure that the right questions are asked, and in a way that permits those asked for answers to respond in a manner that appropriately indicates their own hesitations. The historian's question to an archaeologist or a specialist in DNA analysis might well be "Did Yersinia pestis cause the Black Death?", and the answer might well be "Yes, but ...". If so, it is essential to understand the "buts" as well as the positive assertion.

These papers are intended as a contribution to both sides of a critical problem, in which the gap between sceptics and believers, as can be seen, is smaller than might be assumed at first reading. Whether a totally satisfactory solution can be reached is uncertain, yet by pointing out the questions that need further answers, one may extend still further the areas of agreement and open the way for a far more focused research agenda. ${ }^{75}$

\footnotetext{
${ }^{72}$ Audoin-Rouzeau, op. cit., note 32 above, pp. 358-94.

${ }^{73}$ The importance of variations with molecular DNA is stressed by Florent Sebbane, Clayton O Jarrett, Donald Gardner, Daniel Long and B Joseph Hinnebusch, 'Role of the Yersinia pestis plasminogen activator in the incidence of distinct septicemic and bubonic forms of flea-borne plague', Proc. Natl. Acad. Sciences USA, 2006, 103 (14): 5526-30.

${ }^{74}$ Nils C Stenseth, Noelle I Samia, Hildegunn Viljugrein, et al., 'Plague dynamics are driven by climate variation', Proc. Natl. Acad. Sci. USA, 2006, 103 (35): 13110-115.

${ }^{75}$ The French plague specialist Henri Mollaret, in conversation with Dorothy and Lloyd Moote, emphasized the enormous uncertainties involved in the interaction between bacillus, flea, the rat primary host and humans under the influence of temperature variability, the availability of moisture, proximity to other humans, rats, and fleas, and variation in the virulence of Yersinia pestis, to which might be added the variation in human immune systems.
} 